\title{
LEGAL PROTECTION OF CREDITURS IN THE IMPLEMENTATION OF SUBSIDY CREDIT WITH GUARANTEE SECURITY LETTER
}

\author{
Hosada Esa*, Hartanto Andy \\ Faculty of Law, Narotama University of Surabaya, Indonesia \\ *E-mail: hosadha888@gmail.com
}

\begin{abstract}
In the case of Mortgage buyer can not appear before a Notary or PPAT, Article 15 of the Law Mortgage provides the opportunity for the assigning of dependents to use the Power of Attorney Imposing Mortgage (SKMHT). Based on the research we concluded that, SKMHT this period to be increased to APHT for 1 month to 3 months registered land and for the land has not been registered. This time period according to Article 15 (5) of the Act Mortgage excluded by Minister of State for Agrarian Affairs / Head of National Land Agency Number 4 of 1996 concerning the use of an expiration date SKMHT to guarantee repayment of certain credits. In the area of mortgages, especially for mortgages subsidized SKMHT time period is set during the loan period so that the debtor is not burdened with the cost APHT again. These rules are not in line with the execution of the auction mortgages arranged by auction house KPKNL (the State Property Office and Auction) because the main requirement can be done auction security rights that is the SHT (certificate of encumbrance) in the UUPA.
\end{abstract}

\section{KEY WORDS}

Power subsidy, legal credit, small business, loan guarantee.

The making of SKMHT is possible in the case that the right to land which is the object of the Mortgage Right has not yet been certified. In the mortgage agreement (mortgage) the debtor receiving the loan provides collateral in the form of house and land purchased from the credit facility of the bank. Bank lending bank usually only as the holder of SKMHT alone, because the right of land rights which is the object of guarantee has not been done individually. In the Housing Loan agreement (KPR) there are 3 (three) related parties, namely: the debtor (consumer) party is the buyer of the house built by the developer with the money borrowed from the bank; the creditor party is the bank as a funding bank which provides credit facilities in the form of money used by the debtor to pay for the house purchased from the developer; developers are developers and builders of housing projects ie houses that are sold to buyers either in cash or credit.

To guarantee credit payment in accordance with the terms of the credit agreement, the debtor agrees to provide the house and land purchased with the bank's credit. In Article 4 of Ownership Credit Agreement made by the State Savings Bank, it is stated that if the collateral in the form of house and land is deemed to be insufficient, the debtor may add certain other items which the bank specifies as additional collateral. ${ }^{1}$ Housing Loans (KPR) granted for housing procurement under Article 1 Paragraph (2) of Regulation of the State Minister of Agrarian Affairs / Head of BPN concerning the Stipulation of Deadline for the Use of Power of Attorney to Charge the Guarantee (SKMHT) to guarantee Types of Specific Credits

During the achievements in credit agreements pledged with Rights. Deposit is fulfilled well by the debtor, then the right of dependent as security right does not look its function. New Deposit right works if the debtor has an appointment injury. Article 4 paragraphs (1) and (2) of UUHT determined that what may be the object of Mortgage Right is the right to land from: property rights; cultivation rights; building rights; use rights on state land which by their nature must be registered and transferable.

\footnotetext{
${ }^{1}$ Hermansyah, Hukum perbankan Nasional Indonesia (edisi revisi), Jakarta,Kencana Prenada Media Group, 2005, hlm. 126
} 
Before the promulgation of UUHT, in the practice of banking, the power of attorney to install Hypotics (SKMH) rarely, or almost never done the installation of mortgages in real, on the grounds that cause creditor tidal directly install mortgages among others:

- The process of installing a mortgage is relatively long.

- Bank long enough to know the character of the debtor.

- The cost of mortgage loading is felt very expensive by the debtor, therefore the debtor feels objection if the bank (creditor) requires that it be done directly mortgage installation on the guarantee submitted by the debtor.

In the event that the buyer of Mortgage's Rights cannot be present in the presence of Notary or PPAT, Article 15 UUHT provides an opportunity for the Depositary to use the Power of Attorney for Deposit Rights (SKMHT). The Insurer shall be appointed as the authorized party by SKMHT in the form of authentic and must meet the following conditions:

- Does not contain the power to perform other legal acts other than to impose the Mortgage Right.

- Does not contain substitution power that is the replacement of the authorized recipient through the transfer so that there is a new power of attorney.

- To clearly state the object of the Deposit Rights, the amount of debt and the name and identity of the creditor and debtor

Based on Article 15 paragraph (3) and (4) UUHT, SKMHT is limited period enactment:

- For land already registered SKMHT shall be immediately followed by Deed of Assignment Rights (APHT), no later than 1 (one) month after it is granted.

- For land that has not been registered, the obligation must be fulfilled within 3 (three) months of SKMHT granted.

Elucidation of Article 15 paragraph (5) of UUHT stipulates that the provisions of Article 15 paragraph (3) and (4) do not apply to SKMHT for certain types of credit, namely KUK, KUT, KPR. According to Article 1 of Regulation of the Minister of Agrarian Affairs Number 4 of 1994 concerning the Determination of Time Limit for the use of SKMHT to guarantee the repayment of certain credits, the period of validity of SKMHT "until the expiration of the principal agreement concerned". Related to the provision of subsidized credit or small business loans with a credit limit of 50 million to 250 million which should be every credit tied with mortgage rights in order to process the execution of the object of mortgage rights can be done. Based on Article 3 paragraph 1 of Law No. 4 of 1996 concerning the Rights of Dependance (obviously) the creditor has full rights over the object of the mortgage in case if the debtor is defaulted then the creditor can execute.

As for the predicting of subsidy credit or small business credit as regulated in the Regulation of the Minister of Agrarian Affairs / Head of National Land Agency Number 4 of 1996 stated in Article 2 paragraph 2 (clear) credit with a ceiling of 50 million up to 250 million only in bind with SKMHT not until HT while under the rules related auction execution object collateral / guarantee must with HT over the object. Duration of this SKMHT to be increased to APHT for 1 month for registered land and 3 months for land not yet registered. This period according to Article 15 paragraph (5) UUHT is exempted by Regulation of the Minister of Agrarian Affairs / Head of National Land Agency Number 4 Year 1996 regarding the stipulation of time limit of SKMHT usage to guarantee the repayment of certain credits. In the field of KPR, specifically for the KPR subsidy, the term of SKMHT is stipulated during the loan period so that the debtor is not burdened with APHT fees anymore. The regulation is not in line with the execution of the auction of mortgage rights arranged by KPKNL auction because the main requirement of the auction of mortgage rights is the existence of SHT (certificate of mortgage rights) in the provisions of Law No. 5 of 1960 on Basic Agrarian Basic Regulation (UUPA).

\section{METHODS OF RESEARCH}

The type of research used in the completion of this thesis is the type of normative juridical research. In accordance with the objectives to be achieved, the methodology in this 
thesis research uses two approaches, namely the statute approach and the conceptual approach (conseptual approarch). In collecting this legal material the author uses the method or way by classifying, categorizing and inventorying legal materials used in analyzing and solving problems. ${ }^{2}$

\section{DISCUSSION OF RESULTS}

Execution on Assurance Objects on Subsidized Loans Tied By SKMHT. The substance of SKMHT is limited, that is, it only contains legal law Imposing a Deposit Rights does not contain the right to substitute a power of attorney through a transfer and contains the name and identity of the creditor, debtor, the amount of debt, as well as the object of the Deposit Rights. In addition to the above, to prevent the protracted provision of power and for the achievement of legal certainty SKMHT limited period of validity. Article 15 Paragraph (3) of the Mortgage Act determines against registered lands, SKMHT shall be immediately followed by the establishment of Deed of Assignment Rights (APHT) within a period of 1 (one) month after it is granted. Against the land that has not been registered, the obligation must be fulfilled within 3 (three) months. If the tenure requirement is not fulfilled, SKMHT becomes "null and void" as defined in the provisions of Article 15 paragraph (6) of the Mortgage Act.

The above provisions do not apply in the case of SKMHT granted to secure certain credits, such as program loans, small business loans and mortgage loans (mortgages) and similar credits. The determination of the time limit for the validity of SKMHT for certain types of credit is stipulated in the Regulation of the State Minister of Agrarian Affairs / Head of BPN Number 4 Year 1996 regarding the Determination of the Time Limit of SKMHT validity to guarantee certain types of credit. In the provision of Article 1 of Regulation of the Minister of Agrarian Affairs / Head of BPN Number 4 of 1996 states that, the Power of Attorney imposes a Deposit Rights granted to secure the repayment of types of Small Business Credit as referred to in Decree of the Board of Managing Directors of Bank Indonesia Number 26/24 / KEP / Dir dated May 29, 1993, the following applies to the date of expiry of the principal agreement.

Loans given to small business customers, which include:

- Credit to Village Unit Cooperatives

- Agricultural Credit

- Credit to Primary Cooperatives for Members.

Housing Loans held for housing procurement, namely:

- Credit granted to finance the ownership of a nuclear, simple or flats house with a maximum land area of $200 \mathrm{~m}^{2}$ (two hundred square meters) and a building area of not more than $70 \mathrm{~m}^{2}$ (seventy square meters);

- Loans granted for the ownership of Ready Warehouse (KSB) with a land area of $54 \mathrm{~m}^{2}$ (fifty-four square meters) up to $72 \mathrm{~m}^{2}$ (seventy-two square meters) and credits granted to finance the building;

- Credit granted for repair / renovation of houses as meant in letters $a$ and b.

Other productive credit granted by Commercial Banks and Perkre Bank-ditan Rakyat with credit limit not exceeding Rp. 50.000.000,00 (fifty million rupiah), among others:

a) Rural Public Credit (BRI);

b) Business Feasibility Loan (disbursed by a Government Bank);

Related to the provision of subsidized credit or small business credit with a credit limit of Rp.50.000.000,00 (fifty million rupiah) up to Rp.250.000.000,00 (two hundred fifty million rupiah) which should be every credit tied with the right of dependents to be in the process of execution of the object of mortgage rights can be done. Under the provisions of Article 3 paragraph (1) of the Statutory Rights Act it is clearly stated that the creditor has full rights to the object of such mortgage in case if the debtor is defaulted then the creditor can execute. In the case of subsidized credit credits or small business loans as regulated in the Regulation of the Minister of Agrarian Affairs / Head of the National Land Agency Number 4 of 1996

\footnotetext{
${ }^{2}$ Peter Mahmud Marzuki. Penelitian Hukum. Jakarta, Kencana Prenada Media Group, 2015, hlm. 181
} 
stated in Article 2 paragraph (2) that the credit with a ceiling of Rp.50.000.000,00 (fifty million rupiah) up to Rp.250.000.000,00 (two hundred and fifty million rupiah) is only tied with SKMHT not until the Deposit Rights while under the rules relating to the auction of execution of collateral object / guarantee shall be with the Insured Rights of the object.

Duration of this SKMHT to be increased to APHT for 1 month for registered land and 3 months for land not yet registered. This period of time under Article 15 paragraph (5) of the Mutual Rights Act is exempted under the Regulation of the Minister of Agrarian Affairs / Head of the National Land Agency Number 4 of 1996 on the Determination of Time Limits on the Use of SKMHT to secure the repayment of certain credits. In the field of KPR, specifically for the KPR subsidy, the term of SKMHT is stipulated during the loan period so that the debtor is not burdened with APHT fees anymore. The regulation is not in line with the execution of mortgage auction which is arranged by KPKNL auction because of the main requirement of the auction of mortification right is the existence of SHT (Certificate of Dependent Rights).

Based on the above description, basically the issuance of Regulation of the Minister of Agrarian Affairs / Head of National Land Agency Number 4 Year 1996 on Determination of Time Limit SKMHT Use to guarantee the repayment of certain credits is to facilitate the debtor in the implementation of credit, especially credit subsidy or small business credit, however, in practice it will provide a loss to the creditor in particular in the event of default until the execution, in the absence of a mortgage certificate.

SKMHT is a deed which is authorizing by the landlord / building to the creditor to impose the Mortgage right on the land / building which is used as the debt guarantee. Basically SKMHT is not a guarantee bonding, but it is merely a power to impose the Mortgage Rights and hence the Creditor has not gained the widest possible rights. In this case the position of the creditor is no longer the preferred creditor (preferred creditor), as seen from the elements and the characteristics of the mortgage.

In the Insurance Right Act states that any credit which is collateral in form of land along with objects related to the land shall be installed / burdened by the Mortgage Rights. While the process of making the burden of the Constitution right according to the Act is not always directly with the making in the form of deed is the Deed of Assignment Rights, but preceded by the making of Power of Attorer Charging the Dependent Rights as regulated in Article 15 of the Mortgage Rights Act. Article 15 Paragraph (3) of the Constitution Law states that for the rights to land already registered, the Power of Attorney to impose the Mortgage Right shall be followed by the Deed of granting of dependent right no later than 1 (one) month after the power of attorney to impose the mortification right is signed. Meanwhile, Article 15 Paragraph (4) of the Mortgage Rights Act states that for the rights to land not yet registered, it must be followed by the Deed of granting of dependent right not later than 3 (three) months after the Power of Attorney for Burdening of Mortgage is signed.

The relevant land boundary has been certified but has not been registered on behalf of the Depositors as its new rights holder. Much of what happens in practice, developers do not break their land rights certificates into individual parcels, but they are still in the form of master certificates (which have been measured in accordance with Measurements issued by the National Land Agency). Article 15 Paragraph (6) of the Constitution Law states that within the period referred to in Article 15 Paragraphs (3) and (4), the Power of Attorney to impose the Deposit Insurance must be followed by the creation of the Mortgage Benefit Document. ${ }^{3}$

If such time period is not followed by the making of the Concession Rights, the Power of Attorney shall be canceled by law. As for the issue of law in the implementation of the Power of Attorney often Burdening the Mortgage which has been signed by the Bank I Creditor with the debtor is often null and void, so that the Power of Attorney Charging the Deposit Rights cannot be used to make the Deed of Mortgage Right this is because the Land Rights certificate has not been completed behind the name in accordance or on behalf of the debtor. If this happens then the creditor would be very disadvantaged, because the position of the creditor is not guaranteed with the right of dependents.

\footnotetext{
${ }^{3}$ Munir Fuady, Hukum Perkreditan Kontemporer, Cetakan Ke-2. Edisi Revisi, Bandung : Citra Aditya Bakti, 2002, hlm. 22
} 
With the enforcement of the Mortgage Rights Act is also known Power of Attorney Charging Guarantee (SKMHT), but SKMHT is made before the Deed of Assignment Rights (APHT). In the Mortgage Act, it is desirable to create a Power of Attorney for Deposit Insurance (SKMHT), which must be accompanied by the making of the Deposit Rights. For the validity of a Power of Attorney to impose the Mortgage Right (SKMHT) other than must be made by Notary Deed or the Deed of the Officers of the Deed of Land (PPAT), pursuant to Article 15 Paragraph (1) of the Mortgage Law must also be fulfilled SKMHT requirements:

- Does not contain the power to perform other legal acts rather than impose the Mortgage Right.

- Does not contain the power of substitution.

- To clearly state the Object of Mortgage Rights, the amount of debt and the name and identity of the creditor, the name and identity of the debtor if the debtor is not a Depositary.

From the explanation of Article 15 paragraph (1) of the Mortgage Law, it can be explained that SKMHT is a Power of Attorney granted the Depositary to the creditor as the recipient of the dependent Right to impose the Insurance Rights on the Object of the Dependent Rights. SKMHT is a special power of attorney given by the debtor to a special creditor for the installation of the imposition of the Insurance Rights only. Deposit Rights may also be levied on land rights and existing, existing or existing buildings, plants and works which are united with the land, and which are the property of the holder of land rights whose charges are expressly stated in the Deed of Granting of Works, not owned by the holder of land rights, the imposition of mortgages on such items may only be made by signature as well as on the Deed of granting the relevant Mortgage Rights by the owner or authorized for it by an authentic deed. ${ }^{4}$

The mortgages in the form of buildings, plants, and works such as temples, statues, gates, reliefs that are one with the land concerned. Buildings that can be burdened with mortgage right along with the land include buildings that are above or below the surface of the land such as basement, which has to do with the right to the land concerned. Consequently, the imposition of mortgages on buildings, plants and works which constitute a union with land other than the holder of the land rights shall be conducted simultaneously with the granting of the land title concerned and declared in a Deed of Mortgage Rights, signed together with their owners and holders of the rights to their lands or their powers, both as the mortgagee.

If within the time limit specified in the Mortgage Rights Act is not immediately carried out the creation of the Deed of Assignment Rights (APHT), the Power of Attorney for Imposing the Insured Priority has been null and void. 1 (one) month period restrictions on certified and 3 (three) months of land for non-certified lands in banking practice are felt to be too short because in the practice of generally registered and unregistered land take longer time in the process of handling it, consequently the Power of Attorney Charging the Guarantee Right (SKMHT) is null and void, but it is not possible to create a new APHT, the repetition to make the deed of grant of new Mortgage will give difficulties for the bank. ${ }^{5}$

Thus, it is possible to avoid the cancellation of Power of Attorney for Burdening Rights (SKMHT) within the period referred to in Article 15 paragraph 3 and 4 of the Mortgage Rights Act. The provisions concerning the period referred to in the provisions of Article 15, paragraphs 3 and 4 shall not apply if the Power of Attorney for Assignment (SKMHT) is granted for the provision of certain credits, especially program loans, small business loans, refundable credits and other credits. According to the authors of the provisions regarding the period of time mentioned in Article 15 paragraphs (3) and (4) shall not apply if the Power of Attorney Charging the Mortgage Right (SKMHT) is granted for the granting of certain credits, the making of SKMHT and APHT in the imposition of Mortgage Rights, if it is seen from the order of the Legislation, the decision of the minister allowing the non-validity of SKMHT and

\footnotetext{
${ }^{4}$ Effendi Perangin-angin, Praktik Penggunaan Tanah Sebagai Jaminan Kredit, Jakarta: Rajawali Pers, 1981, hlm. 9

${ }^{5}$ Kartini Muljadi dan Gunawan Widjaja, Perikatan Yang Lahir dari Perjanjian, Jakata : Rajawali Pres, 2003, hlm. 45
} 
APHT to certain credits can not be implemented because it is contrary to the higher regulation namely the Mortgage Rights Act. ${ }^{6}$

In the Registration of Deed of Mortgage Rights (APHT) to obtain the Mortgage Right, it is determined that its management is done within 7 (seven) days and the Mortgage Right itself is born at the time of bookkeeping in the land office land so that the certainty about the time of registration of the Mortgage Right is very important for creditor. Article 13 paragraph 4 of the Mortgage Rights Act specifies that, the date of the Book of Mortgage and the imposition of a Deposit Rights on a land certificate in the land title certificate subject to the Deposit Rights, is the date of the seventh day after the complete receipt of the required letters for registration Mortgage right.

The existence of the grace period in the maintenance for the birth of the Deposit Rights according to the opinion of the writer will be able to harm the interest of the creditor, the loss can occur if within the time period stipulated the Insurance Rights Act that begins the creation of Power of Attorney Charging Guarantee (SKMHT) and the making of the Right Granting Deed Dependence (APHT) and continued with the registration of the right Loan occurred bad credit.

\section{CONCLUSION AND SUGGESTIONS}

The legal power of Subsidized Credit or Small Business Credit with the guarantee of Mortgage Right, that as long as the agreement is made in accordance with the terms of the validity of the agreement (Article 1320 Civil Code), the credit agreement is binding on the parties making it so that to the parties of the agreement the same position as legislation for the parties making it (Article 138 Civil Code). Meanwhile, the collateral made with SKHMT has no impact on the legal standing of the agreement because the collateral agreement is merely an accesoir agreement. Subsidy loans or small-scaled business loans with Deposit Guarantee under Regulation of the Minister of Agrarian Affairs / Head of the National Land Agency Number 4 of 1996 in accordance with the provisions of Article 15 paragraph (5) of the Mortgage Law that the time limit for the validity of Power of Attorney guarantee certain types of credit are exempted from the provisions of Article 15 paragraphs (2) and (3).

With only SKHMT, the creditor's position does not have any privileges as if imposed with APHT, so as a creditor preference he can execute on his own. One of the safeguards is to file a lawsuit against the court with the risk of additional costs incurred during the litigation process in the court. Legal protection of creditors upon default by debtor with a guarantee on subsidized credit or small business credit from the registration of mortgage rights with registration of Deed of Assignment Rights by PPAT for the manufacture of Certificate of Mortgage Right. With the registration of such mortgage security, the publicity principle fulfilled is a guarantee of legal certainty to the creditor in the return of the debtor's receivables. The weaknesses in the implementation of legal protection for the creditor in a mortgage agreement are still many found in practice in the business world of security guarantee objects made by the Deed of Assignment that is not continuously registered to the Land Office or only made under the deed under the hand consequently, the executorial of the deed is lost and the creditor does not get his / her preferential right.

Based on the existing problems and associated with the conclusions that have been mentioned above, it can be given suggestions as follows:

The problems that arise in relation to the concept of land rights implication contained in Article 1 paragraph (1) of Law No. 4 of 1996 can be resolved wisely if the element of trust contained in Giving Mortgage more highlighted. This trust element becomes necessary and important considering the granting of the mortgage rights with the guarantee of land that has not been certified to the debtor who has not been able to guarantee that the granting of SKMHT can be upgraded to the Deed of Assignment Rights (APHT), because the judicial property rights of the debtor have not actually changed from debtors to creditors.

\footnotetext{
${ }^{6}$ Sutan Remy Sjahdeini, Hak Tanggungan Azas-Azas, Ketentuan Pokok dan Masalah Yang Dihadapi Oleh Perbankan (Suatu Kajian Mengenai Undang Undang Hak Tanggungan, Bandung, Alumni, 1999, hlm. 72
} 
The establishment of Law No. 4/1996 on the guarantee of Mortgage Rights and the Regulation of the Minister of Agrarian Affairs / Head of the National Land Agency Number 4 of 1996 is due to the problems arising from the legal need for a strong guarantee institution which can be imposed on the right to land dependent, in addition to accommodate the interests of small entrepreneurs because of limited business capital so no need to certify the rights to his land as collateral and simply submit a girik or petuk that prove his property in a trust only.

Power of Attorney imposes a Deposit Rights due to The debtor can not come directly for the signing or installation of the Deed of Assignment of Collateral on the land and housing guarantee as collateral to the bank or creditor and it is expected that the time period in the Power of Attorney to impose the Mortgage right is not passed, as set forth in the Elucidation of Article 15 paragraph (4) of the Deposit Insurance Law, prior to the issuance of the Mortgage Rights Act to be registered with the Certificate of Mortgage Right at the local Land Office.

\section{REFERENCES}

1. Effendi Perangin-angin, Praktik Penggunaan Tanah Sebagai Jaminan Kredit, Jakarta : Rajawali Pers, 1981

2. Kartini Muljadi dan Gunawan Widjaja, Perikatan Yang Lahir dari Perjanjian, Jakata : Rajawali Pres, 2003

3. Sutan Remy Sjahdeini, Hak Tanggungan Azas-Azas, Ketentuan Pokok dan Masalah Yang Dihadapi Oleh Perbankan (Suatu Kajian Mengenai Undang Undang Hak Tanggungan, Bandung, Alumni, 1999

4. Eugina Liliawati Mulyono, 1996, Eksekusi Grosse Akta Hipotek Oleh Bank, Rinneka Cipta, Jakarta

5. Gunawan Widjaja dan Ahmad Yani, 2000, Jaminan Fidusia, Grafindo Persada, Jakarta

6. H. Tan Kamelo, 2004, Hukum Jaminan Fidusia ; Suatu Kebutuhan Yang Didambakan, Bandung, Alumni.

7. Peter Mahmud Marzuki. 2015, Penelitian Hukum. Jakarta, Kencana Prenada Media Group.

8. Rachmadi Usman, 2003, Aspek-Aspek Hukum Perbankan di Indonesia, Jakarta, Gramedia Pustakatama.

9. Rochmat Soemitro, 1987, Peraturan dan Instruksi Lelang, Eresco, Bandung

10. Sri Soedewi Masjchoen Sofwan, 1998, Hukum Jaminan di Indonesia Pokok-Pokok Hukum Jaminan dan Jaminan Perorangan, Badan Pembinaan Hukum Nasional Departemen Kehakiman, Liberty, Yogyakarta

11. Sutan Remy Sjahdani, 1999, Hak Tanggungan, Asas, Ketentuan-Ketentuan Pokok dan Masalah yang dihadapi oleh Perbankan; Suatu Kajian Mengenai Undang-Undang Hak Tanggungan, Bandung :Alumni, Bandung

12. 2008, Hukum Jaminan Keperdataan, Jakarta Sinar Grafika 